\title{
The Rule of Law at Risk: What is Next?
}

\author{
Renata Uitz ${ }^{1}$
}

Published online: 5 November 2019

(C) The Author(s) 2019

\begin{abstract}
Written for a collection to celebrate the scholarship of Martin Krygier this brief essay explores some thorny questions surrounding the operation of the European Union's mechanisms meant to safeguard the rule of law. It focuses on the hesitation of European constitutional actors to provide legal responses to the chicanery animating the actions of illiberal rulers as well as on the difficulties that follow from Article 7 TEU being framed as a risk assessment exercise.
\end{abstract}

Few defenders of the rule of law are as lucid, passionate and relentless as Martin Krygier. Among the grand masters of theory even fewer are driven by a genuine concern for the practical implications of their ideas and arguments. Martin cares enough about the bricks and mortar of the rule of law to regularly engage with its architects and victims on the ground. This is not hearsay: I had the pleasure of watching him at work - and in his element - away from the air-conditioned comfort of academic venues, in places where ferry passengers share the deck with a noisy band of live poultry or on the roadside with sleepy stray dogs.

When we first met—or rather: when I first encountered Martin-I was a fresh doctoral graduate. At the time the rule of law was a shorthand term for a better future (or at least for a promise thereof). We were concerned about post-communist constitutional courts making a mess of the situation, while doing justice to grave, state-sponsored injustice in the name of protecting constitutionalism and the rule of law. Fine nuances about the difference between the rule of law, Rechtstaat and pravovoye gosudartsvo were being carefully revisited-with the hope that conceptual differences would not stand in the way of a transition to democracy.

At the time, the difference between the rule of law and rule by law was almost tangible. Dangers stemming from an abuse of power felt too real to require much elaboration. And when it was necessary, historians were trusted with the task of sifting through the archives, of taming primary accounts of repression and trauma for the eyes and ears of a wider audience. In the meantime, practitioners of the transition

Renata Uitz

Uitzren@ceu.edu

1 Central European University, Budapest, Hungary 
to democracy were busy with promoting constitutional democracy, human rights and the rule of law, taking it for granted that the seeds thus planted would germinate. The fruits of this exercise appeared to be marketable and measurable, with few concerns about what the numbers in such reports and indexes actually stood for. We were meant to be on a linear trajectory towards global liberal constitutional democracy, on the lookout for the end of history. Over time, promoting the rule of law has become a proxy for a wide range of well-meaning international exchanges with governments that do not wish to go as far as protecting human rights and constitutional democracy. And almost seamlessly, the rule of law was in trouble.

For all these years, Martin's scholarship has been seeking to move the needle-to urge us all to go beyond the classic (and obvious) questions and to explore what we may have missed. At the time of rule of law checklists and indexes, the elegant Krygier distinction urged us to see the rule of law as a teleological concept, and not as an anatomical one. ${ }^{1}$ This juxtaposition seeks to direct attention to the aspirational dimension of the rule of law, a point that is hard to appreciate so long as one takes it for granted that the rule of law-whether thick or thin-is a shared ideal. Distilling this point to its essence in radically simple terms, Martin more recently called the rule of law a "practical ideal" that "can make some difference in the world." 2

This formulation is most helpful in an age of abusive constitutionalism or constitutional chicanery where illiberal and populist rulers rely on constitutional routines and the language of the rule of law for the purposes of self-perpetuation and an abuse of power. Such constitutional chicanery is difficult to prove, because it requires an inquiry into the true-as opposed to the stated-intentions of (often democratically elected) constitutional actors.

The challenge is as old as written constitutions and judicial review. Consider the words of Chief Justice Marshall in McCulloch v. Maryland, 17 U.S. (4 Wheat.) 316, 423 (1819):

Should Congress, in the execution of its powers, adopt measures which are prohibited by the constitution; or should Congress, under the pretext of executing its powers, pass laws for the accomplishment of objects not entrusted to the government; it would become the painful duty of this tribunal, should a case requiring such a decision come before it, to say that such an act was not the law of the land.

As the US Supreme Court's recent jurisprudence illustrates, this is not as trivial an exercise as it sounds, especially when courts are routinely demonized in political as well as in academic circles. A strong presumption of constitutionality together with expectations of judicial deference required the finding of such a pretext to be based on particularly convincing evidence, on pain of a severe political backlash directed at the judiciary.

\footnotetext{
${ }^{1}$ Krygier (2011).

${ }^{2}$ Krygier (2016), p. 222.
} 
Most recently the European Court of Human Rights has attempted to capture illiberal chicanery through the activation of Article 18 of the Convention, the provision that aims to prevent the use of restrictions on human rights "for any purpose other than those for which they have been prescribed." The approach followed by the Court requires thinking outside the usual compartmentalized reasoning that is neatly boxed under distinct Convention articles. The benchmarks for the application of Article 18 were set by the Grand Chamber in Merabishvili v. Georgia ${ }^{3}$ and a year later the Court followed the standards outlined therein in the case of a prominent Azeri human rights defender who was prosecuted for running a civil society organization that accepted funds, including foreign funds, that were otherwise not illegal (Aliyev v. Azerbaijan ${ }^{4}$ ). Accordingly:

\begin{abstract}
200. ... a restriction can be compatible with the substantive Convention provision which authorises it because it pursues an aim permissible under that provision, but still infringe Article 18 because it was chiefly meant for another purpose that is not prescribed by the Convention; in other words, if that other purpose was predominant. Conversely, if the prescribed purpose was the main one, the restriction does not run counter to Article 18 even if it also pursues another purpose. Which purpose is predominant in a given case depends on all the circumstances. In assessing that point, the Court will have regard to the nature and degree of reprehensibility of the alleged ulterior purpose, and bear in mind that the Convention was designed to maintain and promote the ideals and values of a democratic society governed by the rule of law.
\end{abstract}

The test and the manner of proof established by the Court are most extraordinary: "the burden of proof is not borne by one or the other party because the Court examines all material before it irrespective of its origin, and because it can, if necessary, obtain material of its own motion" (202. §). The judgment in Aliyev comes on the coattails of dozens of grave violations of Convention rights in cases where the governments in question routinely and excessively relied on legal formalities to violate the rights of the applicants, many of them human rights defenders. Whether the Venice Commission demonstrates a similar willingness to expose the illiberal chicanery of national governments appears to depend more on the composition of the panel more than on the member state in question or the number of times that the Commission is faced with the same matter.

For the time being the mechanism that appears least helpful in addressing genuine contemporary threats to the rule of law is the one under Article 7 TEU in the European Union. This provision was drafted in 2000 by drafters who were scarred by Austria's Haider affair, at a time when the Union's eastward enlargement was still underway. The aim was to create a preventive mechanism, focusing on warnings, and not on sanctions, in the spirit of building a European Constitution. In the circumstances a mechanism that would warn against "a clear risk of a serious breach" of the rule of law sounded as if it was all that was needed. The word 'clear' - making

\footnotetext{
3 No. 72508/13, Judgment of November 28, 2017.

4 No. 68762/14, 71200/14, Judgment of September 20, 2018.
} 
the threshold of intervention higher-was added rather late in the process, almost as an afterthought. ${ }^{5}$

Since 2010 the shortcomings of the EU's rule of law framework have become painfully familiar. The rise of illiberal democracies (to use the label proudly worn by key practitioners of the genre) triggered a rule of crisis literally for the lack of a better word: the rule of law was the term that was least difficult to associate with the exercise of EU competences in defence of the foundations and founding ideals of the Union. Along familiar mental patterns, it became a shorthand term for protecting constitutional democracy, human rights, the protection of minorities and all those other ideals that are (or at least used to be) associated with the Union as a political project in and beyond Article 2 TEU. While this aspect of the EU language game is widely known, it is often overlooked when Article 7(1) TEU as a mechanism is put into play. Then the rule of law framework is stripped to a bare skeleton, as if all it meant was safeguarding a few institutions and procedures, i.e., the subjects often scored in quantitative studies for rule of law indexes.

The most often lamented weaknesses of the EU's rule of law mechanism include the lack of transparency concerning its key stages, the interlocking political and legal steps that the process involves and the fact that it appears to result in an endless dialogue between EU institutions and national governments that is meant to be conducted in the spirit of sincere cooperation. Almost a decade into the dialogue on the rule of law it is hard to deny that the strategic national actors use the Article 7(1) TEU process as an opportunity to dismantle the rule of law within and with the assistance of the Union.

Even those who chastise European institutions for not acting earlier and in a more decisive manner tend to overlook a crucial feature of this process, as envisioned in Article 7(1) TEU. The preventive mechanism described therein does not require evidence of a serious breach (as in a judicial case) after the fact, but a showing of a clear risk thereof. This is a preventive procedure based on a preliminary risk assessment.

At first sight, risk assessment is not a phrase to make lawyers anxious: the whole idea and industry of insurance is built on it, with its origins in tort law. Risk talk is frequent in our daily lives: we are used to being at risk of disease ' $x$ ' and-as reasonable persons - are trained to start the recommended diet or exercise routine without delay (at least in principle). We are even used to the idea of carrying lethal risks in our DNA: threats of particular genetic diseases prompt people to undergo radical surgical interventions to prevent dreaded consequences. Managing risks is so much in the culture of contemporary constitutional democracies that we stopped being wary about the impact of our risk and threat matrixes on those who are put beyond the presumption of innocence and due process in an effort to prevent much-feared future events. It helps that the targets of these risk assessment tools are the likes of sex offenders or suspected terrorists, i.e., subjects who are easy to dismiss. Indeed, risk talk is so prevalent that we have grown intellectually immune to it.

\footnotetext{
${ }^{5}$ Sadurski (2010), pp. 405-413.
} 
A critical reflection on how risks and threats are conceptualized for scholarship on the rule of law is important, as some scholars of constitutional government are growing impatient with the tyrannophobia of those who are trying to raise the alarm about the rise of populism, and especially illiberal rule. Metaphors that overstate the impact of particular measures endangering the rule of law (e.g., calling a court packing bill a constitutional coup) are as easy to dismiss as a metaphoric exaggeration calling illiberal politicians fascists for emphasis. Of course, saying that liberal scholarship on constitutionalism and the rule of law has always had the weakness of crying tyranny hardly explains the difficulties in identifying the clear risk that should make a political community (like the EU) worry about the rule of law. Yet, if we cannot identify such a clear risk, can we pinpoint an actual attack on the rule of law?

When scholars of law and politics provide a meticulous record of illiberal legal measures undermining the rule of law-somewhat ironically - the evidence comprised of technical legal steps often gets in the way of telling the story of what happened to the rule of law in the course of these events. The excessive legal formalism of illiberal regimes does not make anyone living under them feel safe: authoritarian regimes of the most evil kind are known to follow the letter of the law and use the law as a tool of repression. The incremental nature of response mechanisms (one case at a time before one body) appears to prevent a proper assessment of the cumulated, overall impact of those allegedly minor, technical measures. It is not only pointless, it is harmful to deny that practitioners of constitutional chicanery are good students of the rule of law: they protest when European political actors make comments on events that are the subject of a case pending before a court. In a similar spirit, they cry out if in a new case against them instances of previous violations are referred to: the principle of double jeopardy should prevent such a monstrous injustice.

Sensing that contemporary scholarship on the rule of law is slowly losing a grip on its subject, Martin recently called for studying the rule of law by means of a "social science that does not quite yet exist." 6 Taking up this invitation on account of the earlier discussion on the rule of law and risk assessment, it is worth noting that scholars of the regulatory state are well aware that the perception of risk is affected by personal experiences; more precisely, that people's perception of risk is impaired by all kinds of misjudgments (cognitive biases). Thus, understanding what risk assessment and risk management takes in defence of the rule of law, it is time to include the study of the rule of law as a human experience in this much needed new social science.

Indeed, we have a well-established record in the social sciences, humanities and arts on what the absence of the rule of law feels like. Although evil regimes around the world have provided ample evidence over the years, the subject is not a study of the experiences of distant 'others,' of remote ancestors, or of people in far-away dictatorships. In most proud constitutional democracies there are many such 'others' who live in the abyss of the rule of law due to their skin colour, origin, social class or even gender. Their experiences should also help with understanding the illiberal

\footnotetext{
${ }^{6}$ Krygier (2016), p. 222.
} 
experience of the rule of law slipping away grain after gain as a handful of sand between our fingers.

A purposeful and critical inquiry into the rule of law as a contemporary human experience in illiberal democracies appears to be essential not only for studying the rule of law as a practical ideal, but also for defending it from its worst enemies: those masters of constitutional chicanery who use the language of the rule of law to claim ideals that they were never meant to have. Martin issued the invitation for this journey, and he is the best companion for this adventure.

Acknowledgements Open access funding provided by Central European University.

Open Access This article is distributed under the terms of the Creative Commons Attribution 4.0 International License (http://creativecommons.org/licenses/by/4.0/), which permits unrestricted use, distribution, and reproduction in any medium, provided you give appropriate credit to the original author(s) and the source, provide a link to the Creative Commons license, and indicate if changes were made.

\section{References}

Krygier M (2011) Four puzzles about the rule of law: why, what, where? And who cares? In: Fleming JE (ed) Getting to the rule of law. NOMOS 50. New York University Press, New York, pp 64-104

Krygier M (2016) The rule of law: pasts, presents, and two possible futures. Annu Rev Law Soc Sci 12:199-229

Sadurski W (2010) Adding bite to bark: the story of Article 7, E.U. enlargement, and Jorg Haider. Columbia J Eur Law 16:385-426

Publisher's Note Springer Nature remains neutral with regard to jurisdictional claims in published maps and institutional affiliations. 